Nibras, S.M., Abeynayake, M., Gowsiga, M. and Dilakshan, R., 2019. Facilities management value addition in corporate social responsibility. In: Sandanayake, Y.G., Gunatilake, S. and Waidyasekara, A. (eds). Proceedings of the $8^{\text {th }}$ World Construction Symposium, Colombo, Sri Lanka, 8-10 November 2019, pp. 330-339. DOI: doi.org/10.31705/WCS.2019.33. Available at: https://2019.ciobwcs.com/papers

\title{
FACILITIES MANAGEMENT VALUE ADDITION IN CORPORATE SOCIAL RESPONSIBILITY
}

\author{
S.M. Nibras ${ }^{1}$, M. Abeynayake ${ }^{2}$, M. Gowsiga ${ }^{3}$ and R. Dilakshan ${ }^{4}$
}

\begin{abstract}
Corporate activities have a major impact on society environment, thus the concern and pressure on corporate activities become a recurrent theme. Especially, the operations of corporates in the built environment is highly violated with the well-being of employee, customer, society, and environment. To overcome the impacts of the built environment operation, corporates need to adopt an effective management practice within the built environment as a part of their social responsibility. Facilities Management (FM) is a profession, which manages the built environment effectively. Therefore, this research aimed at assessing the value addition of FM in social responsibilities of the corporates through effective built environment management practices. Initially, situational analysis was conducted to identify the existing CSR practices in Sri Lanka and then the FMvalue added practices in key areas of CSR were found to achieve the aim. A qualitative research approach was adopted and seven (07) semi-structured expert interviews were carried out for data collection and two (02) interviews were carried out to validate the findings. The results of the content analysis revealed that CSR practices are relatively at a low level in Sri Lanka. As well as, most of FM professionals are involved in the operational and tactical level function. However, facilities managers perform energy management, water management, waste management, asset management and maintenance management, health and safety, stakeholder management, compliance management, risk management, procurement and contract management and workplace management roles in an organisation. Throughout those FM practices, part of CSR of an organization could be fulfilled.
\end{abstract}

Keywords: Built Environment; Corporate Social Responsibility, Facilities Management; Social Well-being.

\section{INTRODUCTION}

The corporates are the major key driver of global development where they generate a large number of goods and services, employment and economic benefits to the countries (Feijoo et al., 2014). However, the intention of profit making in business activities lead to negative impacts such as environmental pollution, resource depletion, health and safety issues and poverty in the society (Martinez, 2012). Also, corporate activities are violated with society (Supanti et al., 2015). Hence to minimise those issues, CSR concept was developed in early 1950 and its demand is continuously increasing due to the

\footnotetext{
${ }^{1}$ Department of Building Economics, University of Moratuwa, Sri Lanka, smoh.nibras@gmail.com

${ }^{2}$ Department of Building Economics, University of Moratuwa, Sri Lanka, mabeynayake@uom.lk

${ }^{3}$ Department of Building Economics, University of Moratuwa, Sri Lanka, gowsigam@uom.lk

${ }^{4}$ Department of Building Economics, University of Moratuwa, Sri Lanka,

dilakshanrajaratnam@gmail.com
} 
globalisation and adverse effect of competition among the corporates (Jamali and Mirshak, 2007). CSR is defined as a set of activities undertaken by the corporates in order to show their social and environmental commitment to neighbourhoods (Marrewijk, 2003). The CSR concept is not a philanthropic responsibility, it discusses environmental, employee, legal, ethical and community development responsibilities of the corporates (Turker, 2009). Central Bank of Sri Lanka (CBSL) reported that the corporate sector is the major revenue creator and employment provider in the Sri Lankan economy (2015). However, their social and environmental consideration for the well-being of society is at a low level (Rajmanthri, 2005). The CSR concept exists as a new concept in Sri Lanka, not all corporates are following it due to the lack of knowledge in areas of CSR (Rathnasiri, 2003). Further, there is a requirement of a contribution of the professionals in the company to eliminate the social and environmental impact of the corporates. In that respect, some of FM activities are having a great potential for ensuring social well-being through effective built environment management (Conely, 2017). FM functions such as health and safety, energy and water management and workplace management have great potential to add value in social and environmental responsibility of the corporates (Jensen et al., 2014). Moreover, FM professionals can take a strategic role in CSR initiation of the company for delivering an effective strategic plan to CSR policy (Redlein et al., 2015). Nevertheless, the involvement of facilities managers in the CSR initiation and policy creation is rare in the current practice. Although FM has great potential to add value on CSR (Jensen et al., 2012) on the contrary, there is no research has been so far undertaken on value addition of FM in CSR (Jensen, 2010). Hence, the aim of this research is to address this gap by review the FM value addition in the social and environmental well-being of society through the built environment management of corporates. The structure of the paper launches with a literature review related to significant concepts of the study. Then it presents the method used in achieving the aim of the study and finally, it presents the discussion on research findings together with conclusions and the recommendations.

\section{LITERATURE REVIEW}

"CSR is the obligations of businessmen to pursue those policies, to make decisions, or to follow those lines of action which are desirable in terms of the objectives and values of our society" (Bowen, 1953). It is businesses taking care of their society, environment and interaction with their stakeholders which is used as a tool to businesses show their role in society and reputation (Lichtenstein et al., 2004). Moreover, the definitions vary due to the differentiation in the country, business culture and social, ethical behaviours and used different areas to describe the CSR. Table 1 illustrates the areas of CSR discussed in the definitions. Conclusively, it has concluded that six (06) main areas which are health and safety and welfare of employees, environment protection, ethical behaviour, legal compliance, economic development and philanthropic responsibilities of the companies. The first and foremost responsibility of an organisation toward its employee is to ensure their safety and satisfaction in the workplace (Montero et al., 2009). Moreover, the organisations should have health and safety policies, workplace monitoring practices, proper training programmes, providing entertainment facilities to reduce stress and tired of employees in order to improve the employees' health and safety at the workplace (Peloza and Shang, 2011). 
Table 1: Definitions of CSR

\begin{tabular}{lcccccc}
\hline \multicolumn{1}{c}{ Authors } & \multicolumn{6}{c}{ Areas } \\
\cline { 2 - 7 } & Community & Economic & Legal & Ethical & Philanthropic & Environmental \\
\hline Frederick (1960) & $\sqrt{ }$ & $\sqrt{ }$ & & $\sqrt{ }$ & & $\sqrt{ }$ \\
Carroll (1979) & & $\sqrt{ }$ & $\sqrt{ }$ & $\sqrt{ }$ & $\sqrt{ }$ & $\sqrt{ }$ \\
Maignan (2001) & $\sqrt{ }$ & $\sqrt{ }$ & $\sqrt{ }$ & & $\sqrt{ }$ & $\sqrt{ }$ \\
Sharma and & & $\sqrt{ }$ & $\sqrt{ }$ & & $\sqrt{ }$ & $\sqrt{ }$ \\
Mehta (2012) & & $\sqrt{ }$ & $\sqrt{ }$ & $\sqrt{ }$ & $\sqrt{ }$ & \\
Lindgreen and & $\sqrt{ }$ & & & & & \\
Swaen (2010) & & & & & &
\end{tabular}

Corporate activities are highly contributed to the Green House Gas emission (2008), and it pollutes water reservoirs, groundwater, fauna and flora and biodiversity by releasing wastewaters, solid waste and chemicals (Gadenne et al., 2009). Thus, CSR emphasise to follow the energy efficient, water conservation, renewable energy usage, waste management practices and plantation programs to protect the environment (Lyon and Maxwell, 2008).

Then, the ethical responsibility emphasises business owners need to create a set of terms to carry out the business activities without doing harm to society. Even though it does not enforce by the law, the organisation creates its own value and norms to treat the employee, customers, suppliers, competitors and debtors fairly and respectively (Lantos, 2001). Further, corporates have a responsibility to respect and follow the legal regulation because law and regulations are created to ensure the well-being of society by avoiding harmful activities of peoples and firms (Chen, 2011). The legal responsibility includes the compliance of labour practices with labour law and health and safety regulations, following environmental regulations when operating the plant and waste disposal, compliance with the contract and property laws (Guay et al., 2004). The economic responsibility is to emphasise being a profitable organisation maximise shareholder value, strategies for competitive advantage and use of human and natural resources to achieve economic objectives through social activities (Garriga and Mele, 2004). Also, it as integrity, corporate governance and economic development of the community, transparency, prevention of bribery and corruption, payments to national and local authorities, use of local suppliers, hiring local labour and similar areas (Asemah et al., 2013). Moreover, philanthropic responsibilities are the volunteer responsibilities of the enterprise (Lambooy, 2014). It includes donations of goods and services, volunteering activity, the involvement of the enterprise in the community development (Nurn and Tan, 2010).

The above discussed responsibilities are closely related to the built environment of the corporates. Hence, managing built environment to reduce the social and environmental impacts is the social responsibility of an organisation (Lyon and Maxwell, 2008). In that respect, FM is an emerging profession to support the core business of the organisation by effective management of facilities, people, workplace and technology in the built environment (Chotipanich, 2004), and it is a rapidly growing sector over the years due to the increased importance for managing support services to meet the needs of the core business (Musa and Pitt, 2009). Further, the role of FM in the organisations enhances the business continuity through the effective management of support services to core business 
function (Junghans and Olsson, 2014). International Facilities Management Association (IFMA, 2017) defined, FM is a profession that encompasses multiple disciplines to ensure the functionality of the built environment by integrating people, place, process and technology. The term multiple disciplines cover a wide range of activities such as real estate management, engineering and maintenance, risk management, health and safety, human resource management, environment and sustainability, contract management and utility management (Kamaruzzaman and Zawawi, 2010). Further, facilities managers are engaging with customers, employees, service partners and the community to manage economic, environmental and social impact of the organisation and to deliver stakeholder value in community based FM (Alexander and Brown, 2006). In addition, Isa and Kamaruzzaman (2017) argued that FM functions are closely related to the value management because owners can gain benefits for their investment in the building development when it lasts a long time and functioning with the cost effective operation and maintenance. In that respect, CSR is an area where FM is expected to have great potential to add value in terms of environment aspect together with social aspect (Jensen et al., 2014).

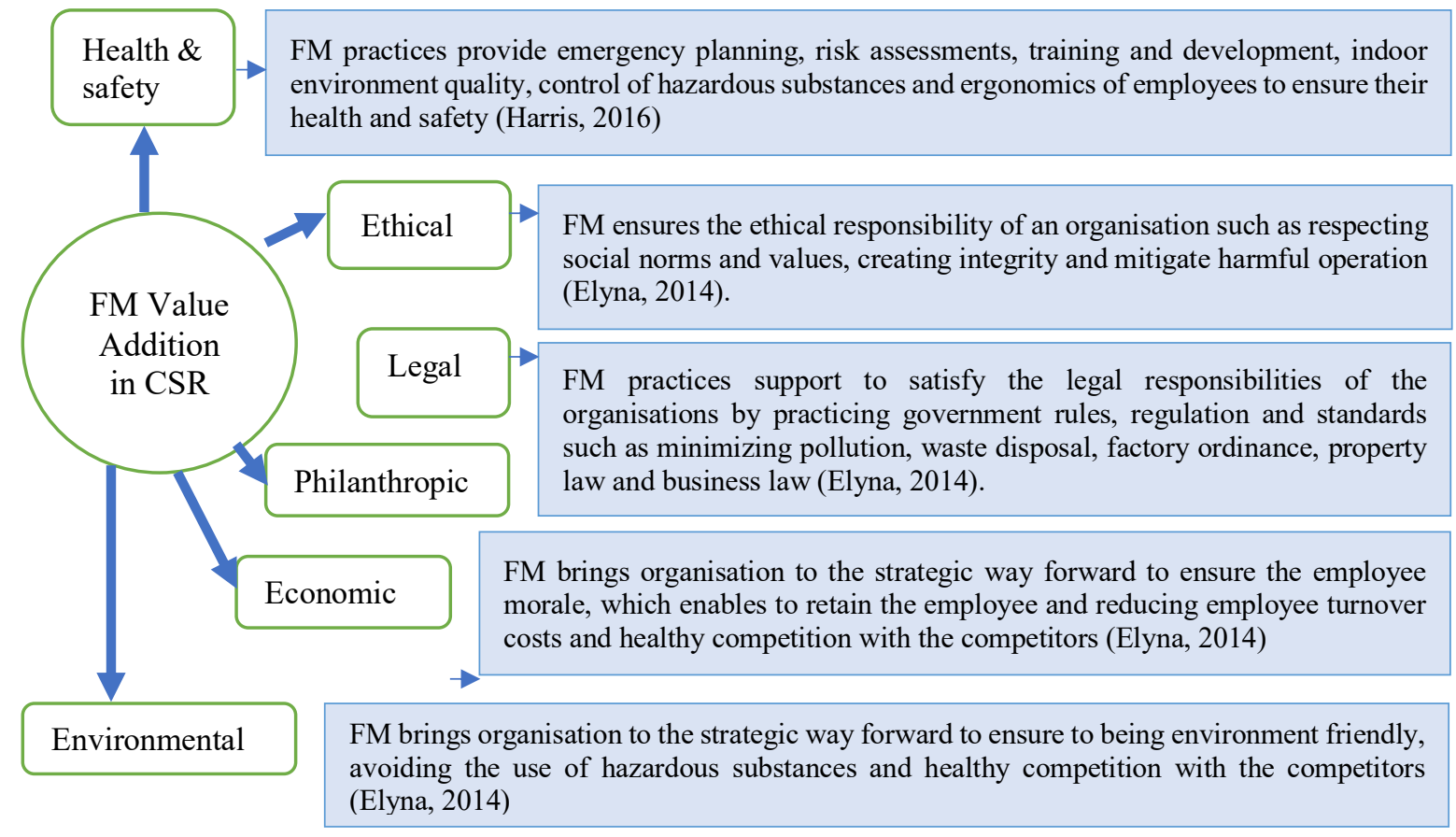

Figure 1:FM value addition in CSR

\section{RESEARCH METHODOLOGY}

The aim of the study is to review the FM value addition in the social and environmental well-being of society through the built environment management of corporates. Agreeing with the nature of this study, a qualitative approach was chosen due to its holistic view of the research problems and qualitative researches are well structured, transparent and easy to understand. Accordingly, semi structured interview was selected as the data collecting tool to reach and explore complete and clear answers for any new research topics (Creswell, 2008). Expert interviews, are most suitable techniques in case of there are no enough researches and data available for the study (Hamza, 2014) with semi structure interview format, which is provided with an opportunity to the interviewee for acknowledging own views regarding the social issue (Saunders, 2009) were selected. The 
details of the experts are shown in Table 3. All three (03) experts of CSR were selected from the socially responsible companies in Sri Lanka and who have engaged in CSR practices. The FM experts who engaged in the built environment. Collected data were analysed by content analysis method by using NVivo12 software. Finally, the research findings were validated with two (02) expert interviews.

Table 3.: Details of selected organisations

\begin{tabular}{lllll}
\hline Expertise & Interviewee & \multicolumn{1}{c}{ Sector } & \multicolumn{1}{c}{ Designation } & Experience \\
\hline CSR & $\mathrm{S}_{\mathrm{A}}$ & Retail and Finance & Senior Commercial Manager & 10 Years \\
& $\mathrm{S}_{\mathrm{B}}$ & $\begin{array}{l}\text { CSR consultancy } \\
\text { service }\end{array}$ & $\begin{array}{l}\text { Knowledge Management and } \\
\text { Corporate Engagement Officer }\end{array}$ & 8 years \\
& & Telecommunication & Human Resource Manager & 8 years \\
\hline FM & $\mathrm{S}_{\mathrm{C}}$ & FM Service Provider & Head of Business & 8 years \\
& $\mathrm{F}_{\mathrm{A}}$ & FM Service Provider & General Manager (FM) & 24 years \\
& $\mathrm{F}_{\mathrm{B}}$ & Office & Facilities Manager and Deputy & 7 years \\
& $\mathrm{F}_{\mathrm{C}}$ & head of Corporate Service & \\
& & & Quality Assurance Coordinator & 8 years \\
\hline
\end{tabular}

\section{RESEARCH FINDINGS AND DISCUSSION}

This section discusses the finding of this study of FM value addition in areas of CSR into six (06) subs heading namely Health and Safety and Welfare of Employees, Environmental protection, Ethical Responsibility, Legal compliance responsibility, Economic responsibility and Philanthropic responsibility.

\subsection{FM VALUE AdDition In AREAS OF CSR}

While FM support to the core business function of the companies, the experts highlighted that FM has a significant role to add value in CSR. FM is not only adding value to the economic viability of the organisation, but also delivering social and environmental value too. "Do you think FM practices can influence social well-being? If yes, briefly describe it" through this question, the views about CSR of FM professionals understood. $\mathrm{F}_{\mathrm{A}}$ specified, CSR is about what businesses are adding value to its employees, customers, environment and the society beyond the goods and service they provide. In addition, $\mathrm{F}_{\mathrm{C}}$ and $\mathrm{F}_{\mathrm{D}}$ noted, "CSR is about companies voluntarily taking responsibility for the social and environmental impact of their operation". Moreover, F $F_{B}$ statement evidenced that the companies have responsibilities to fulfil the expectation of the society beyond the owner's benefits. Additionally, all four of them were agreed with the FM has a significant role to add value in CSR. $\mathrm{F}_{\mathrm{A}}$ stated that FM is not only adding value to the economic viability of the organisation, but also delivering social and environmental value too. However, most of them are seeing FM as a property management practice in Sri Lanka. Further, $F_{B}$ stated as, FM supported to enhance the well-being of the community, even though they do not have a CSR policy through energy saving, water conservation and waste management. In addition, $\mathrm{F}_{\mathrm{C}}$ statement also similar with $\mathrm{F}_{\mathrm{A}}$ statement, the impact of the FM practices is not only extended within the organisation and its building but also impact the society and environment. To identify the FM value addition on the CSR, the data was collected under the six areas of the CSR as mentioned above and each area is described below. 


\subsubsection{Health and Safety and Welfare of Employees}

The professional behaviour of FMs ensure the rights of employees and avoid any potential situation for employee violations. $F_{A}$ stated that role of FM in health and safety is vital to ensure the well- being of employees and $F_{B}$ mentioned that in the built environment, facilities managers are the most competence professionals in this area. All the FM experts were mentioned the same practices of FM in employee health and safety. However, only $\mathrm{F}_{\mathrm{A}}$ and $\mathrm{F}_{\mathrm{B}}$ mentioned the avoidance of employee violations under the health and safety practices and explained, in line with professional ethical standards of the facilities manager, have to perform their role where they ensure the rights of employees and avoid any potential situation for the employee violations. Also, $\mathrm{F}_{\mathrm{A}}$ ensuring employee health and safety is a part of legal obligation as well as the social responsibility of the businesses. In addition, $F_{B}$ and $F_{C}$ stated facilities managers have a major part in this area due to having responsibility of policy creation and compliance with the local and international regulatory requirements. Apart from that, all the interviewees were discussed about hazard identification and elimination, workplace monitoring, emergency preparedness practices during the fire, chemical exposure and blasting, employee training and stakeholder communication functions of FM. Added to that, $F_{D}$ listed following as the responsibility of FM which has to disclose the accident information in the built environment as part of social responsibility.

\subsubsection{Environmental Protection}

"Sustain of the environment is important for well- being of the human and animals in the planet" stated by $F_{B}$ and $F_{D}$ argued about releasing GHG emission, wastage of resources and excessive energy uses are the main reason for the global warming and which are handle and recorded by FM professionals. As said by the CSR experts, companies should have a clear environmental policy to ensure the effectiveness of environmental protection process. Alike, FM experts were noticed that FMs have a major role in the environmental policy creation in the organisations. According to $\mathrm{S}_{\mathrm{B}}$, "corporate built environment is highly contributed to climate change by consuming high energy, GHG emission and pollute the air and water reservoirs. Therefore, organisations are concerned with the environment protection as their social responsibility". FM experts were discussed how FM practices are contributed to minimise the environmental effect of organisations activities. In that respect, $\mathrm{F}_{\mathrm{B}}$ and $\mathrm{F}_{\mathrm{C}}$ mentioned eco-friendly purchasing practices which are selecting less carbon or carbon neutral materials, reusable and recyclable products, less energy usage and environmentally friendly dispose products for manufacturing and end-use purposes. Additionally, compliance with the environmental management standards and regulatory practices of facilities managers such as environment protection license, monitoring and reporting, environmental impact assessment, energy audits were mentioned.

\subsubsection{Ethical Responsibility}

The FM profession highly deal with the employees, suppliers, contractors and other facility related parties in the society for organisation purposes. Therefore, facilities managers have a responsibility to ensure the rights of employees such as workplace safety, equality, and fair wages and work hour. Also, they support to the organisation toward the clients through the fair dealing with the clients by avoiding any harms to their properties. Further, ethical responsibility is to avoid harmful activities to society. $\mathrm{F}_{\mathrm{C}}$ defined ethical responsibility as "behaving fairly and transparently with the employee, 
customers, suppliers and society" and $\mathrm{F}_{\mathrm{A}}$ said, even though FM has no any relationship with organisation's customers, it is linked with the employee and society. Moreover, $\mathrm{F}_{\mathrm{A}}$ and $F_{C}$ were stated that generally violation of employees is occurred in the workplaces due to the different behaviours and disciplines of employees. Therefore, facilities managers using different methods to identify the potential for the employees' violations and resolve it in the early stage to ensure the rights of other employees in the organisation. The CSR experts defined ethical responsibility as doing good things to society. Further, mentioned as avoiding environmental harmful activities as an ethical responsibility because it causes a negative impact on society. Similarly, all FM experts noticed that FM practices are eliminated those environmental harmful operations in the built environment. In addition, $F_{B}$ and $F_{D}$ stated the main function of the $F M$ is integrating people, place, process and technology for the functionality of a built environment. Hence, people are important part of FM. Thus, fulfilling expectations and respecting the cultural and social values are important to facilities managers in order to ensure the social responsibility of the organisation toward the community.

\subsubsection{Legal Compliance Responsibility}

Legal responsibility of corporates discussed respect and compliance with local and international standards, rules and regulation which are enacted by the government to direct the business activities in an ethical way. Corporate activities are generally linked with different laws and FM practices ensure the compliance of the corporate built environment activities along with the law and regulation. Thus, facilities managers create health and safety policies and environmental policies as per the requirement of local and international standards and regulation and practicing it standards manner. $F_{A}$ and $F_{B}$ stated that facilities managers are managing the health and safety of the built environment in order to secure the peoples from the hazards. Moreover, $\mathrm{F}_{\mathrm{C}}$ indicated that those health and safety management practices are designed based on the local and international standards and regulatory requirements. Further interviewee $F_{D}$ mentioned that facilities managers are ensuring mechanical and electrical services are complied with the standards, obtaining license and certificates regarding air and water quality, implementing health and safety standards and following the regulatory guidance for ensuring the safety of employees, customers and visitors. In addition, according to $\mathrm{F}_{\mathrm{D}} \mathrm{FMs}$ must aware of the environmental problems and create the solution in accordance with the standards and regulations. Further, $F_{A}$ and $F_{B}$ stated that FMs are carried out the environmental assessments, obtaining an environment protection license, monitoring and reporting practices as part of compliance with the standards. Moreover, contract management activities were mentioned by $\mathrm{F}_{\mathrm{B}}, \mathrm{F}_{\mathrm{C}}$ and $\mathrm{F}_{\mathrm{D}}$ and in addition, they specified that facilities managers are entered into the facilities related contracts on behalf of client or owners with different service providers. They have a responsibility to keeping this contractual relation without breaching any obligations, bribery and corruption as well. Moreover, $\mathrm{F}_{\mathrm{A}}, \mathrm{F}_{\mathrm{B}}$ and $\mathrm{F}_{\mathrm{D}}$ were stated the real estate property management role of FM, which ensure the compliance with areas of property law such as ownership, tenancy, possession, leasing, property rights and dispute solution. Further, documentation practices of facilities managers enable the availability of records as per the legal requirements.

\subsubsection{Economic Responsibility}

The foremost economic responsibility of corporate is to be a profitable organisation due to their responsibility to provide economic benefits to its owners, employees, creditors 
and society. $\mathrm{F}_{\mathrm{A}}$ and $\mathrm{F}_{\mathrm{D}}$ only discussed the $\mathrm{FM}$ role in the economic responsibility of CSR. In that respect, interviewee $F_{A}$ and $F_{D}$ argued that $F M$ has consisted of a different economy related disciplines such as prepare more accurate future capital budgets, finding solutions to specific problems in the built environment, controlling capital resources required to support operations, reduction in procurement cost, saving in energy consumption of the facility and improvement of overall work environment with more flexible and cost effective which enable to profit maximization of the company. Therefore, facilities management support to the economic responsibility of the companies in terms of profit maximization. In addition to that, FM practices ensure the efficient use of the human, physical, financial and technology resources of the organizations. So, FM support to the economic responsibility in terms of cost saving, risk avoiding and efficient use of resources. However, interviewee $F_{B}$ and $F_{C}$ did not mention the $F M$ role in economic responsibility.

\subsubsection{Philanthropic Responsibility}

According to all four FM experts' statements, FM does not have any value addition in the philanthropic responsibility of the company. Because, philanthropic activities include donations, public welfare, education and the environment-based volunteer activities of the company. Therefore, FM practices not related to philanthropic activities.

\section{CONCLUSIONS}

According to the CSR experts, corporates have a responsibility to concern the social issues along with the profit maximisation and have become the main element of economic development and human resource development in Sri Lanka. However, corporates activities have a major impact on the society and environment. Thus, there is a need for socially responsible business operation among the corporates. According to the finding, there is a lack of knowledge and practices regarding the CSR among the Sri Lankan corporate sectors. Thereby, most of the organisations follow CSR as a philanthropic activity. When considering the social and environmental impact of the corporates' built environment performance, it has a significant effect on employee health and safety, environmental pollution, energy and water conservation, resource depletion, employee violations, legal negligence and sustainability. In addition, CSR experts revealed few companies are following energy saving, waste management and water efficiency for their profit maximization purposes, not for the social conservation. Further, corporates are not giving priority to the environment effect of corporate activities. Also, there is no legal provisions in Sri Lanka for businesses to carry out operations with the socially responsible manner. Therefore, they practice health and safety, fair dealing with the stakeholders and compliance with regulations for avoiding penalties when violation arise with the labour laws, contract law, environment and factory ordinance regulation. Experts in CSR stated that corporates should engage with effective CSR initiatives with the all professional participants in the organisation to overcome those issues. In that respect, this research was conducted to identify the FM value addition in CSR. Accordingly, FM experts accepted with FM value addition on following areas of CSR, Employee health and safety, Environment protection and avoidance of nuisance, Ethical responsibility, Legal compliance and Economic responsibility by the following activities of FM, such as health and safety, environmental management, eco-friendly purchasing and housekeeping, creating supportive corporate culture, energy saving, emergency preparedness, waste management, resource management and risk management practices, which are adding 
value to core business in terms of profitability and functionality. As well as, it is adding value to the wellbeing of society. Therefore, FM has a major role in the CSR.

\section{REFERENCES}

Alexander, K. and Brown, M., 2006. Community-based facilities management. Facilities, 24(7/8), pp.250268.

Anker Jensen, P., van der Voordt, T., Coenen, C., von Felten, D., Lindholm, A.L., Balslev Nielsen, S., Riratanaphong, C. and Pfenninger, M., 2012. In search for the added value of FM: what we know and what we need to learn. Facilities, 30(5/6), pp.199-217.

Annik , M. F., 2006. Environmental management and corporate social responsibility. Clean Technologies and Environmental Policy, 8(4), pp.217-220.

Asemah , E., Okpanachi, R. and Edegoh , L., 2013. Business Advantages of Corporate Social Responsibility Practice: A Critical Review. Journal of Business Management, 18, pp.114-125.

Bowen, H., 1953. Social Responsibilities of the Businessman. New York: Harper.

Carroll, A. B., 1979. A three-dimensional conceptual model of corporate social performance. Academy of Management Review, 4(4), pp.497-505.

Central Bank of Sri Lanka [CBSL], 2015. Annual Report 2015, Sri Lanka.

Chen, C., 2011. The major components of corporate social responsibility. Journal of Global Responsibility, 2(1), pp.85-99.

Chotipanich, S., 2004. Positioning facility management. Facilities, 22(13/14), pp.364-372.

Conely, B., 2017. Investing in the Future with CSR. Facility Management Journal, pp.45-109.

Creswell, J. W., 2008. Editorial: Mapping the Field of Mixed Methods Research. Journal of Mixed Methods Research, 3(2), pp.95-108.

Elyna, M. N., 2014. Facilities management: the business enabler. Journal of Facilities Management, 12(4), pp.11-16.

Feijoo, B. F., Romero, S. and Ruiz, S., 2014. Effect of Stakeholders' Pressure on Transparency of Sustainability Reports within the GRI Framework. Journal of Business Ethics, 122(1), pp.53-63.

Frederick, W. C., 1960. The Growing Concern Over Business Responsibility. California Management Review, pp.54-61.

Fred, R., 2008. Why corporate social responsibility should be popularised but not imposed. Corporate Governance, 8(3), pp.330-341.

Gadenne, D. L., Kennedy, J. and McKeiver, C., 2009. An Empirical Study of Environmental Awareness and Practices in SMEs. Journal of Business Ethics, 84(1), pp.45-63.

Garriga, E. and Melé, D., 2004. Corporate Social Responsibility Theories: Mapping the Territory. Journal of Business Ethics, 53(1-2), pp.51-74.

Guay, T., Doh, J. P. and Sinclair, G., 2004. Special Issue on Ethical Investment and Corporate Social Responsibility. Journal of Business Ethics, 52(1), pp.125-139.

Hamza, A., 2014. Interviewing as a Data Collection Method: A Critical Review. English Linguistics Research, 3(1), pp.53-60.

Harris, R., 2016. New organisations and new workplaces: Implications for workplace design and management. Journal of Corporate Real Estate, 18(1), pp.4-16.

International Facilities Management Assosiation(IFMA), 2017. [Online] Available at: http://www.ifma.org/about/what-is-facility-management [Accessed 24 march 2017].

Jamali, D. and Mirshak, R., 2007. Corporate social responsibility (CSR): theory and practice in a developing country context. Journal of Business Ethics, 72(3), pp.243-262.

Jensen, P., 2010. The Facilities Management Value Map: a conceptual framework. Facilities, 28(3/4), pp.175-188.

Jensen, P., Voordt , T., Coenen, C. and Sarasoja, A., 2014. Reflecting on future research concerning the added value of FM. Facilities, 32(13/14), pp.856-870. 
Junghans, A. and Olsson, N., 2014. Discussion of facilities management as an academic discipline. 32(1/2), pp.67-79.

Kamaruzzaman , S. N. and Zawawi , E. A., 2010. Development of facilities management in Malaysia. Journal of Facilities Management, 8(1), pp.75-81 .

Lambooy, T., 2014. Legal Aspects of Corporate Social Responsibility. Utrecht Journal of International and European Law, 30(78), pp.1-6.

Lantos, G. P., 2001. The boundaries of strategic corporate social responsibility. Journal of Consumer Marketing, 18(7), pp.595-632.

Lichtenstein, D. R., Drumwright, M. E. and Braig, B. M., 2004. The Effect of Corporate Social Responsibility on Customer Donations to Corporate-Supported Nonprofits. Journal of Marketing, Volume 68, pp.16-32.

Lindgreen , A. and Swaen, V., 2010. Corporate Social Responsibility. International Journal of Management Reviews, 12(1), pp.1-7.

Lyon, T. P. and Maxwell, J. W., 2008. Corporate Social Responsibility and the Environment: A Theoretical Perspective. Review of Environmental Economics and Policy, 1(0), pp.1-22.

Maignan, I., 2001. Consumers' perceptions of corporate social responsibilities. A cross- cultural comparison. Journal of Business Ethics, 30(1), pp.57-72.

Marrewijk, M., 2003. Concepts and Definitions of CSR and Corporate Sustainability: Between Agency and Communion. Journal of Business Ethics, 44(2-3), pp.95-105.

Martinez, J. B., 2012. International Corporate Social Responsibility: The Role of Corpo rations in the Economic Order of the $21^{\text {st }}$ Century. Alphen aan den Rijn: Kluwer Law international.

Montero, M. J., Araque, R. A. and Rey, J. M., 2009. Occupational health and safety in the framework of corporate social responsibility. Safety Science, 47(10), pp.1440-1445.

Musa, Z. and Pitt, M., 2009. Defining facilities management service delivery in UK shopping centres. Journal of Retail and Leisure Property, 8(3), pp.193-205.

Nurn, C. W. and Tan, G., 2010. Obtaining intangible and tangible benefits from corporate social responsibility. International Review of Business Research Papers, 6(4), pp.360-371.

Peloza, J. and Shang, J., 2011. How can corporate social responsibility activities create value for stakeholders? A systematic review. Journal of the Academy of Marketing Science, 39(1), pp.117-135.

Rajmanthri, S., 2005. Effects of Corporate Social Responsibility (CSR) on organizational sustainability: A case study of the Sri Lankan Corporate Sector. Social Responsibility Journal, 1(3/4), pp.149-152.

Rathnasiri, H., 2003. Corporate social responsibility practices of Sri Lankan private sector: an exploratory study. Sri Lanka Journal of Management, 8(3/4), pp.195-228.

Redlein, A., Loesch, J. and Fuke, F., 2015. Corporate Social Responsibility (CSR) and Facility Management (FM) in Europe. International Journal of Facilities Management, 6(1), pp.15-25.

Reese, C. D., 2003. Occupational Health and Safety Management. New York: Lewis Publishers.

Saunders, M., Lewis, P. and Thornhill, A., 2009. Research methods for business students. Harlow: Pearson Education.

Sharma, S.K. and Mehta, S., 2012. Where Do We Go from Here? Viewing Corporate Social Responsibility through a Sustainability Lens. Journal of Contemporary Management Research, 6(2), pp.69-76.

Strachan, P., Sinclair, I. and Lal, D., 2003. Managing ISO 14001 implementation in the United Kingdom Continental Shelf (UKCS). Corporate Social Responsibility and Environmental Management, 10, pp.50-63.

Supanti, D., Butcher, K. and Fredline, L., 2015. Enhancing the employer-employee relationship through corporate social responsibility (CSR) engagement. International Journal of Contemporary Hospitality Management, 27(7), pp.1479-1498.

Turker, D., 2009. How corporate social responsibility influences organizational commitment. Journal of Business Ethics, 89, pp.189-204. 